\title{
Preference and performance of the larvae of Lymantria dispar (Lepidoptera: Lymantriidae) on three species of European oaks
}

\author{
Slobodan MiLANOVIĆ ${ }^{1,5}$, Jelica LAZAREVIĆ 2 , Zorica POPOVIĆ ${ }^{2}$, Zoran MiLETIĆ ${ }^{3}$, MiroslaV KOSTIĆ 4 , \\ Zlatan RADULOVIĆ ${ }^{3}$, Dragan KARADŽIĆ ${ }^{5}$ and Ana VULETA ${ }^{2}$

\begin{abstract}
${ }^{1}$ Department of Forest Protection and Wildlife Management, Faculty of Forestry and Wood Technology, Mendel University, Zemědělská 3, 61300 Brno, Czech Republic; e-mail: slobodan.milanovic@mendelu.cz

${ }^{2}$ Institute for Biological Research, University of Belgrade, Bulevar Despota Stefana 142, Belgrade 11000, Serbia; e-mails: jellaz@ibiss.bg.ac.rs; zorica.popovic@ibiss.bg.ac.rs; ana.vuleta@ibiss.bg.ac.rs

${ }^{3}$ Institute of Forestry, Kneza Visešlava 3, Belgrade 11000, Serbia; e-mails: zoranmil@ptt.rs; zlatan.radulovic@gmail.com
\end{abstract} \\ ${ }^{4}$ Institute for Medicinal Plant Research, Tadeuša Košćuška 1, Belgrade 11000, Serbia; e-mail: mkostic@mocbilja.rs
}

${ }^{5}$ University of Belgrade Faculty of Forestry, Kneza Višeslava 1, Belgrade 11000, Serbia; e-mails: slobodan.milanovic@sfb.bg.ac.rs; dragan.karadzic@sfb.bg.ac.rs

Key words. Lepidoptera, Lymantriidae, Lymantria dispar, Quercus, herbivore-plant interactions, foliar chemistry, feeding preference, nutritional indices

\begin{abstract}
The gypsy moth, Lymantria dispar (L.) (Lepidoptera: Lymantriidae), causes enormous damage to broadleaved forests in the northern hemisphere where it frequently defoliates large areas of forest. Since outbreaks begin in oak forests, its most suitable habitat, we determined the preference and performance of gypsy moth larvae when reared on three species of native oaks: sessile oak, Quercus petraea (Matt.) Liebl.; Turkey oak, Q. cerris L.; and Hungarian oak, Q. frainetto (Ten.). Leaf expansion and selected physical and chemical characteristics of the oak leaves were also measured. The shortest development time and highest relative consumption (RCR), growth rate (RGR), assimilation efficiency (AD), efficiency of conversion of ingested food (ECI) and digested food into larval biomass (ECD) values were recorded when larvae were fed on Turkey oak. Two-choice tests revealed that Turkey oak is the preferred host plant. It had the highest total soluble protein and leaf nitrogen content, lowest $\mathrm{C} / \mathrm{N}$ ratio and its phenology was well synchronized with the hatching of the larvae. The worst performance and lowest preference index were recorded when fed on Hungarian oak, the leaves of which had the lowest protein and nitrogen content, while in terms of the values for preference and performance the larvae fed on sessile oak were intermediate. Our results indicate that forests with Turkey oak are highly likely to be defoliated by gypsy moth larvae and therefore should be regularly monitored.
\end{abstract}

\section{INTRODUCTION}

The gypsy moth, Lymantria dispar L. (Lepidoptera: Lymantriidae) is one of the most serious pests of hardwood forests throughout the northern hemisphere (Elkinton \& Liebhold, 1990). Frequent outbreaks of gypsy moths cause a great deal of damage and result in loss of radial growth (Muzika \& Liebhold, 1999, 2001; Naidoo \& Lechowicz, 2001; Fajvan et al., 2008), changes in fruiting (Gottschalk, 1990) and forest decline (Davidson et al., 1999). Particularly affected is Southeast Europe, where outbreaks are frequent (Marović et al., 1998; Pernek et al., 2008). Since the outbreaks cannot be reliably predicted, it is necessary to prevent permanent damage by monitoring gypsy moth populations over large areas.

Cyclic variation in population density is affected by the individual quality of gypsy moth larvae and environmental factors such as temperature, humidity, natural enemies and host plants (Valentin et al., 1983; Elkinton \& Liebhold, 1990; Rossiter, 1994; Berryman, 1996). As a generalist species, the gypsy moth commonly encounters spatial and temporal variation in food quality, which may be altered by defoliation (Valentin et al., 1983; Rossiter et al., 1988), humidity (Kleiner \& Montgomery, 1994), mineral ferti- lization (Giertych et al., 2005), level of atmospheric $\mathrm{CO}_{2}$ (Traw et al., 1996; Couture et al., 2012) etc. Its successful development and reproduction depend on the nutritional quality, physical characteristics, toxicity and phenology of its host plants as well as behavioral and physiological ability of gypsy moth larvae to overcome the negative effects of nutritive and/or allelochemical stress (Rossiter et al., 1988; Lindroth et al., 1997; Lazarević et al., 2002; Mrdaković et al., 2013). Gypsy moth host plants have been ranked in terms of their suitability based on the degree to which they are defoliated and fitness traits (survival, growth) of the larvae and their preference for feeding on these plants (Liebhold et al., 1995).

During latent periods in their population dynamics, the gypsy moth feeds on the most suitable hosts, i.e., oaks (Quercus spp). Therefore, it is necessary to focus the monitoring on oak forests where outbreaks begin. Of the 20 species of oaks described in the Atlas of the Flora of Europe, 12 occur in the Balkans (Jalas \& Suominen, 1987), but only three species - sessile oak, Quercus petraea (Matt.) Liebl.; Turkey oak, Q. cerris L.; and Hungarian oak, $Q$. frainetto (Ten.) - are of economic importance. 
Sessile oak has the most northerly distribution, reaching latitude $60^{\circ} \mathrm{N}$ in the Baltic region (Axelrod, 1983). It grows on plains on most types of soil from sea level up to an altitude of $1800 \mathrm{~m}$ (Ducousso \& Bordacs, 2004). Turkey oak grows naturally from central and south-eastern Europe to Asia Minor (Şen et al., 2011), but over the last 500 years has been extensively planted north of its native range in Europe. Hungarian oak occurs in thermophilic deciduous forests in Southeast Europe, extending from the Aegean coast of Anatolia to the Apennine Peninsula (Abbate et al., 1990). It is most widespread on the Balkan Peninsula, where it occurs scattered within a broad belt of vegetation rich in woody species (Konstantinidis et al., 2002) and is well adapted to summer drought (Horvat et al., 1974). Given the wide distribution and economic importance of these three species of oaks, and the frequency and extent of gypsy moth outbreaks in oak forests, information on the feeding behaviour of this pest could be useful for management purposes.

Some studies on the feeding preferences of European gypsy moth populations indicate there is no difference in their preference for the species of oaks tested (Kurir, 1953; Györfi, 1960), whereas others carried out in North America indicate that oaks differ greatly in their suitability for gypsy moths (Valentine \& Talerico, 1980; Liebhold et al., 1995; Foss \& Rieske, 2003). Some studies on European oaks (Cambini \& Magnoler, 1997; Magnoler \& Cambini, 1997) and sessile and Turkey oaks (Schopf et al., 1999) also indicate they differ in their suitability as a food source for gypsy moth.

To estimate the risk of defoliation we compared the preference and performance of gypsy moth larvae fed on the leaves of the three species of oaks of economic importance that occur on the Balkan Peninsula: sessile oak, Turkey oak, and Hungarian oak. We also compared the phenology and physical and chemical traits of their leaves, which might account for the differences in gypsy moth preference and performance.

\section{MATERIAL AND METHODS}

\section{Insects}

Egg masses used in the experiments were collected from a plantation of Euro-American poplar Populus $\times$ euroamericana in autumn of 2008. First the eggs were mechanically cleaned of hairs by gentle pressing an egg mass through a piece of gauze using a plug of cotton wool and then the viable eggs were surface disinfected by soaking them in $0.1 \%$ sodium hypochlorite for 5 $\mathrm{min}$. The eggs were then rinsed with distilled water for $10 \mathrm{~min}$ and finally dried. After this the eggs were kept in a refrigerator at $4^{\circ} \mathrm{C}$ until the beginning of the experiments.

Viable eggs from 25 egg masses were mixed and placed in tubes. One hundred eggs from each egg mass were transferred to the Arboretum for hatching in January 2009. Hatching in the laboratory was initiated after $50 \%$ of the eggs transferred to the Arboretum had hatched (mid-April). Initiation of hatching of the eggs in the laboratory was done by placing them in climate chamber kept at $25^{\circ} \mathrm{C}$.

\section{Host plants}

For testing the performance and preference of gypsy moth larvae, four to six trees of sessile oak, Turkey oak and Hungarian oak, each aged approximately 60 years, were selected and marked in the Arboretum of the Faculty of Forestry in Belgrade. In order to standardize the effect of environmental factors on bud burst these trees were all located within a $50 \times 50 \mathrm{~m}$ area, at the same altitude and with the same exposure.

\section{Characteristics of leaves}

Leaf development was recorded from the beginning of April until the middle of May 2009; leaf length measurements were taken twice a week to the nearest $0.5 \mathrm{~cm}$. Upon completion of leaf development, the percentage of leaf development for each period was determined, based on the relationship between the average leaf length at that time and the average leaf length at the end of the leafing process. This was performed separately for each tree.

Leaves for chemical analysis were collected in the middle of May. Phenol and tannin analyses were carried out according to the FAO/IEAE laboratory manual (Makkar, 2000). Fresh leaves were collected from four trees per species of oak. Leaves collected from each tree $(n=7-8)$ were mixed and ground in liquid nitrogen. Lyophilized finely ground leaf material was suspended in $50 \%$ methanol $(10 \mathrm{mg} / \mathrm{ml})$ and subjected to ultrasonic treatment. After 20 min of extraction at room temperature, insoluble material was removed by centrifugation and re-extracted. The supernatants were mixed and used in further analyses. Tannin content was determined by two methods. First method, the colorimetric Folin-Ciocalteu method, is based on the reducing property of tannins as phenols and their ability to bind to polyvinyl polypyrrolidone (PVPP) (Makkar et al., 1993; Makkar, 2000). Phenols were detected in the extract before and after treatment with PVPP and the tannin content was the difference between these two values. The other method (Makkar et al., 1988; Makkar, 2000) depends on the biological activity of tannins, i.e. their capacity to bind proteins. After the formation of a complex between tannins from plant extracts and bovine serum albumin as a protein, bounded tannins were measured by ferric chloride assay. Tannic acid (Sigma-Aldrich-403040) was used as a standard and total phenol and tannin contents were expressed as mg of tannic acid equivalents per $100 \mathrm{mg}$ of dry leaf mass.

To determine total soluble protein content dry leaf tissue was extracted in $0.1 \mathrm{M}$ potassium phosphate buffer $(\mathrm{pH}$ 7.0) with $0.1 \%$ Triton X-100, 5\% PVPP and $2 \mathrm{mM}$ phenylmethylsulfonyl fluoride (PMSF). After centrifugation, the supernatant was assayed for soluble proteins according to Bradford (1976).

Leaf samples for carbon and nitrogen analysis were dried for $48 \mathrm{~h}$ at $40^{\circ} \mathrm{C}$. Total carbon content was determined by wet combustion in $\mathrm{CrO}_{3}$ and $\mathrm{H}_{2} \mathrm{SO}_{4}$ using the method of Ansttet, modified by Ponomarieva \& Plotnikova (1975). Total leaf nitrogen was determined using the Kjeldahl method. The destruction of the sample was performed in sulphuric acid in the presence of a catalyst $\left(\mathrm{CuSO}_{4}\right.$ and $\left.\mathrm{K}_{2} \mathrm{SO}_{4}, 1: 3\right)$ until all organic nitrogen was converted into ammonia. Distillation of ammonia was done using a Kjeldahl apparatus and the distillate collected in orthoboric acid (Rhee, 2001). Prior to determination of leaf water content and specific leaf weight, leaves were scanned and measured before and after drying for $72 \mathrm{~h}$ at $65^{\circ} \mathrm{C}$.

\section{Preference test}

Gypsy moth larvae were grown in a climatic chamber (Sanyo) on an artificial medium (MP Biomedicals, Inc.) in Petri dishes $(120 \times 15 \mathrm{~mm})$ at $23^{\circ} \mathrm{C}, 65 \% \mathrm{r}$.h. and a photoperiod of $15 \mathrm{~L}: 9 \mathrm{D}$ until they moulted to the second larval instar. After moulting, larvae were separated and starved for $24 \mathrm{~h}$. Petri dishes for the 
preference tests were prepared as follows. A 2-mm thick layer of agar-water $(2 \%)$ was poured into each Petri dish $(90 \times 14 \mathrm{~mm})$ and after it solidified covered with filter paper. Leaf disks $(15 \mathrm{~mm}$ diameter) of two different oak species were placed in each Petri dish according to the $\mathrm{ABABAB}$ design and fixed with pins of different colours. After preparation of the Petri dishes, one larva was placed in the center of each dish to rule out the possibility of choosing of a particular kind of leaf by chance. To preserve the freshness of the leaf disks the filter paper was slightly moistened. We tested the preference of gypsy moth larvae in the three possible pair combinations for the three species studied. For each combination 30 larvae were tested. At the end of the experiment, the remains of the disks were scanned (200 dpi resolution, jpg form) to determine the area of each leaf consumed in the pair using the ImageTool software package (UTHSCSA). Consumed area was calculated as the difference between area of uneaten disks (a sample of 30 disks) and the area remaining after feeding. For the preference ranking of the oaks, we calculated the Preference Index by dividing the number of pairs in which one species of oak was preferred (greater area consumed) by the total number of pairs for that species (60). We also calculated relative preference as percentage based on the ratio between the area of one species of oak consumed and the total area consumed within each combination of oaks. A species was preferred if the percentage of its area consumed was greater than that of the other species in the pair.

\section{Performance test}

Gypsy moth larvae were grown in a climatic chamber (Sanyo) on artificial medium (MP Biomedicals, Inc.) in Petri dishes $(120 \times 15 \mathrm{~mm})$ at $23^{\circ} \mathrm{C}, 65 \%$ r.h. and a photoperiod of $15 \mathrm{~L}: 9 \mathrm{D}$ until they moulted to the fourth larval instar. After moulting, larvae were separated and grown separately on leaves of Turkey oak, Hungarian oak and sessile oak, until the end of the fourth larval instar. Thirty larvae were fed separately on the leaves of each of the three species of oaks in Petri dishes $(120 \times 15 \mathrm{~mm})$. Leaves were collected from trees that were located in the Arboretum of the Faculty of Forestry in Belgrade.

Thirty larvae from the same experimental group were measured. Their weight was measured at the beginning of the experiment, i.e., after moulting to the fourth larval instar, and after drying at $65^{\circ} \mathrm{C}$ for 3 days. Differences between the fresh and dry weights were used to calculate the dry weight of larvae at the beginning of the experiment. The weight at the end of the experiment (beginning of the fifth larval stage) was measured after drying.

Faeces and leaf remains were collected during the experiment, dried and used to calculate nutritional indices using the formulas of Waldbauer (1968), with the exception of relative growth rate (RGR). RGR was calculated using the weight at the beginning of the fourth and fifth larval instars, using the formula of Farrar et al. (1989).

RGR (relative growth rate $)=\left(\mathrm{m}_{5}-\mathrm{m}_{4}\right) /\left(\mathrm{dl}_{4} \times \mathrm{m}_{4}\right)$ $\mathrm{RCR}$ (relative consumption rate) $=\mathrm{m}_{\mathrm{c}} /\left(\mathrm{dl}_{4} \times \mathrm{m}_{4}\right)$ $\mathrm{AD}$ (assimilation efficiency) $=\left(\mathrm{m}_{\mathrm{c}}-\mathrm{m}_{\mathrm{e}}\right) / \mathrm{m}_{\mathrm{c}} \times 100$ ECI (efficiency of conversion of ingested food $)=$ $\left(\mathrm{m}_{5}-\mathrm{m}_{4}\right) / \mathrm{m}_{\mathrm{c}} \times 100$

$\operatorname{ECD}($ efficiency of conversion of digested food $)=$ $\left(\mathrm{m}_{5}-\mathrm{m}_{4}\right) /\left(\mathrm{m}_{\mathrm{c}}-\mathrm{m}_{\mathrm{e}}\right) \times 100$

where $\mathrm{dl}_{4}-$ duration of fourth larval stage (days); $\mathrm{m}_{4}-$ larval weight at the beginning of the fourth larval instar; $m_{5}$ - larval weight at the beginning of the fifth larval instar (measured with head capsule and exuvium of fourth-instar larva); $m_{c}$ - weight of food consumed; $\mathrm{m}_{\mathrm{e}}$ - weight of faeces.

\section{Statistical analysis}

Statistical analysis was performed using the software package Statistica 6.0 (StatSoft, Inc.). Analysis of differences in leaf development was performed using repeated ANOVA on the $\sqrt{ }(x+0.5)$ transformed data. Differences in the chemical composition of leaves were determined by ANOVA of log-transformed data or arcsine transformed percentages. The percentages of areas of leaves consumed in the two-choice test were also arcsinetransformed and compared using t-test for dependent samples. To evaluate differences in performance of caterpillars fed on the three species of oaks we used an ANCOVA followed by Duncan multiple range test, with the exception of the duration of the fourth larval instar (d14). The initial weight of the caterpillars was used as the covariate for calculation of RCR and RGR. The weight of food consumed was the covariate for AD and ECI, and the difference between the weight of food consumed and weight of faeces was the covariate for ECD. To disentangle pre- and post-ingestive host plant effects on ECI we also compared the ECI values by ANOVA. If both ANCOVA and ANOVA reveal a significant host plant effect on ECI we conclude that changes in food consumption (pre-ingestive behavioral trait) as well as changes in nutrient digestion and absorption or allelochemical detoxification (post-ingestive physiological traits) contribute to the observed variation in the ECI. Otherwise, if a significant effect is only indicated by the ANOVA, then the variation in ECI is just a consequence of behavioural responses to host plants.

\section{RESULTS}

\section{Leaf characteristics}

The results of the analyses of total phenol, tannin and soluble protein contents in leaves of the oak species tested are presented in Table 1. Leaves of Turkey oak had the highest and Hungarian oak the lowest values of these traits.

TABLE 1. Foliar characteristics (mean $\pm \mathrm{SE}$ ) of the three species of oaks compared using ANOVA (F and P values) and Duncan multiple range tests. Means in the same row followed by the same letter do not differ significantly $(\mathrm{P}<0.05)$. d.f. - degrees of freedom.

\begin{tabular}{lcccccc}
\hline Foliar characteristics & Turkey oak & Sessile oak & Hungarian oak & F & d.f. & P \\
\hline Specific leaf weight $\left(\mathrm{mg} / \mathrm{cm}^{2}\right)$ & $4.51(0.19) \mathrm{a}$ & $5.14(0.09) \mathrm{b}$ & $4.58(0.32) \mathrm{a}$ & 5.93 & 2,113 & 0.0035 \\
Water content (\% in fresh weight) & $66.3(0.34) \mathrm{a}$ & $61.0(0.31) \mathrm{b}$ & $56.1(0.44) \mathrm{c}$ & 98.18 & 2,67 & $<0.0001$ \\
Total phenols (mg TAeq/100 mg) & $6.10(0.69) \mathrm{a}$ & $3.49(0.48) \mathrm{b}$ & $3.07(0.36) \mathrm{b}$ & 7.49 & 2,9 & 0.0122 \\
PVPP-tannins (mg TAeq/100 mg) & $5.55(0.66) \mathrm{a}$ & $3.15(0.48) \mathrm{b}$ & $2.63(0.33) \mathrm{b}$ & 7.20 & 2,9 & 0.0136 \\
BSA-tannins (mg TAeq/100 mg) & $1.46(0.06) \mathrm{a}$ & $0.97(0.17) \mathrm{b}$ & $0.83(0.10) \mathrm{b}$ & 7.74 & 2,9 & 0.0111 \\
Total soluble protein $(\mathrm{mg} / 100 \mathrm{mg})$ & $0.48(0.03) \mathrm{a}$ & $0.42(0.01) \mathrm{b}$ & $0.36(0.01) \mathrm{c}$ & 12.84 & 2,9 & 0.0023 \\
N (\%) & $2.2(0.10) \mathrm{a}$ & $2.0(0.04) \mathrm{a}$ & $1.7(0.10) \mathrm{b}$ & 7.31 & 2,10 & 0.0110 \\
C (\%) & $34.7(1.54) \mathrm{a}$ & $34.7(0.82) \mathrm{a}$ & $33.1(1.54) \mathrm{a}$ & 0.47 & 2,10 & 0.6397 \\
C/N & $16.1(0.37) \mathrm{a}$ & $17.4(0.75) \mathrm{a}$ & $19.6(0.60) \mathrm{b}$ & 8.81 & 2,10 & 0.0062 \\
\hline
\end{tabular}




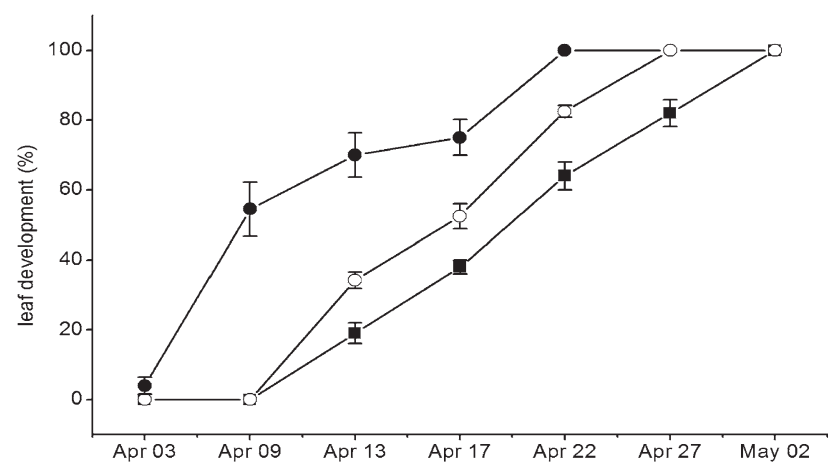

Fig. 1. The relationships between percentage leaf development (mean $\pm \mathrm{SE}$ ) and time for the three species of oak studied $(\bullet-$ sessile oak; ○- Hungarian oak; - Turkey oak).

Leaves of Turkey oak had the highest and Hungarian oak the lowest nitrogen and water content. $\mathrm{C} / \mathrm{N}$ ratio of Turkey oak leaves was the lowest and that of those of Hungarian oak the highest. Intermediate values of these traits were recorded for sessile oak, which also had the highest specific leaf weight, which indicates leaf toughness.

Analysis of variance of repeated measurements showed statistically significant differences in leaf development among the oaks during the observation period April $3^{\text {rd }}$ April $27^{\text {th }}(\mathrm{F}=16.20$; d.f. $=16, \mathrm{P}<0.0001)$. At the first measurement (April $3^{\text {rd }}$ ) sessile oak had already started leafing and its leaves were fully developed on April $22^{\text {nd }}$. On April $13^{\text {th }}$ the Turkey and Hungarian oaks started to leaf. The leaves of Hungarian oak were fully developed on April $27^{\text {th }}$ and those of Turkey oak on May $2^{\text {nd }}$. During most of this period the development of the leaves of Turkey oak lagged behind those of Hungarian oak.

\section{Larval preference}

Oak species were ranked on the basis of gypsy moth larval food choice in two-choice assays. The preference index was highest for Turkey oak (0.65), moderate for sessile oak (0.50) and lowest for Hungarian oak (0.35). Second-instar larvae preferred Turkey oak leaves over those of the other two species, which is also indicated in the positive $t$ values in the t-tests (Fig. 2). Sessile oak leaves were preferred over those of Hungarian oak. If larvae were offered a choice between Turkey and sessile oak leaves or between sessile and Hungarian oak leaves there were no differences between percentages of the areas of these leaves consumed.

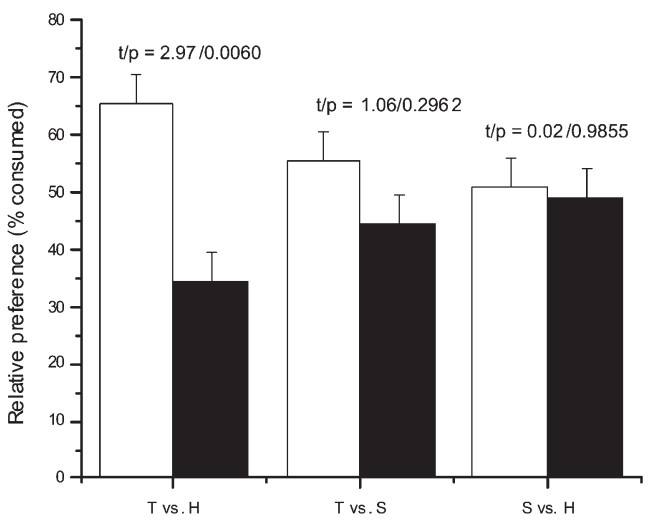

Fig. 2. The relative preference in terms of area of leaf consumed (mean $\pm \mathrm{SE}$ ) by $2^{\text {nd }}$ instar gypsy moth larvae in two choice tests of three combinations of the species of oaks: Turkey vs. Hungarian oak (T vs. H), Turkey vs. sessile oak (T vs. S) and sessile vs. Hungarian oak (S vs. H). The comparison of the percentages of area consumed in each choice test was done using $t$ tests ( $t$ and $p$ values are presented above the columns).

\section{Larval performance}

Significant host plant effects on the duration of development of $4^{\text {th }}$ instar larvae were revealed by ANOVA and growth and nutritional indices were compared using ANCOVA (Table 2). The highest values of nutritional indices (RCR, RGR, AD, ECD and ECI) and shortest duration of development of $4^{\text {th }}$ instar larvae were recorded for those larvae fed on Turkey oak and they performed worst when fed on leaves of Hungarian oak. Since significant differences in ECI among oaks were obtained using both ANO$\mathrm{VA}(\mathrm{F}=8.63, \mathrm{P}=0.003)$ and ANCOVA (Table 2$)$ it appears that both pre- and post-ingestive processes were affected by feeding on leaves of these species of oaks. Intermediate performance traits were recorded when reared on the leaves of sessile oak. Relative growth rate (RGR) is the product of consumption (RCR) and gross growth efficiency (ECI), which depends on assimilation efficiency (digestibility, AD) and net growth efficiency (ECD). Homeostatic adjustment of these parameters may keep the growth rate constant. Although, larvae fed on leaves of sessile oak consumed a smaller leaf area than those fed on leaves of Hungarian oak they grew faster because they had a higher efficiency of conversion of ingested food into insect biomass than the latter. Despite the lower digestibility of the leaves of Hungarian oak, larvae fed on this host plant had a higher ECD and slightly higher relative consumption rate

TABLE 2. Performance (mean \pm SE) of fourth-instar gypsy moth larvae reared on leaves of the three species of oaks compared using ANCOVA, except for d14 values which were compared using ANOVA ( $\mathrm{F}$ and $\mathrm{P}$ values). Means followed by the same letter do not differ significantly (Duncan test, $\mathrm{P}<0.05$ ). $\mathrm{N}$ - number of individuals; d.f. - degrees of freedom. Other abbreviations are explained in Material and Methods.

\begin{tabular}{lcccccc}
\hline \multirow{2}{*}{ Oak species } & \multicolumn{5}{c}{ Larval performance } \\
\cline { 2 - 7 } & $\mathrm{d} 14$ & RGR & RCR & AD & ECI & ECD \\
\hline Turkey oak $(\mathrm{N}=40)$ & $5.7(0.12) \mathrm{a}$ & $0.22(0.0101) \mathrm{a}$ & $6.29(0.655) \mathrm{a}$ & $63.0(4.36) \mathrm{a}$ & $5.8(0.70) \mathrm{a}$ & $25.3(8.30) \mathrm{a}$ \\
Sessile oak $(\mathrm{N}=39)$ & $6.2 \pm 0.13 \mathrm{~b}$ & $0.08(0.0040) \mathrm{b}$ & $1.82(0.076) \mathrm{b}$ & $47.5(2.09) \mathrm{b}$ & $4.7(0.21) \mathrm{b}$ & $11.4(1.12) \mathrm{c}$ \\
Hungarian oak $(\mathrm{N}=39)$ & $7.5(0.16) \mathrm{c}$ & $0.05(0.0025) \mathrm{c}$ & $2.21(0.192) \mathrm{c}$ & $41.8(3.18) \mathrm{b}$ & $2.8(0.19) \mathrm{c}$ & $13.0(3.47) \mathrm{b}$ \\
$\mathrm{F}($ d.f. $=2,114)$ & 47.36 & 116.19 & 36.79 & 11.64 & 58.95 & 76.33 \\
$\mathrm{P}$ & $<0.0001$ & $<0.0001$ & $<0.0001$ & $<0.0001$ & $<0.0001$ & $<0.0001$ \\
\hline
\end{tabular}


and relative growth rate compared to those fed on leaves of sessile oak.

\section{DISCUSSION}

Successful exploitation of host plants by phytophagous insects depends on accepting a host as a suitable source of food and oviposition site as well as their efficiency in utilizing host nutrients. These processes mainly depend on plant physical and chemical attributes. For example, leaf toughness is a good predictor of host preference (Pearse, 2011) and the nitrogen and water content affect the growth and nutritional indices of insects (Mattson, 1980; Martin \& Van't Hof, 1988; Hemming \& Lindroth, 1995; Lindroth et al., 1997; Barbehenn et al., 2004; Chen et al., 2004). In addition, since leaf phenology changes over time and nutritional needs of insects change during development it is important for insect to be well synchronized with budburst of its host plants (Ivashov et al., 2002; van Asch \& Visser, 2007). Change in tannin concentration in leaves during the growing season affects the feeding and growth of insects (Feeny, 1970; Ossipov et al., 2001; Salminen et al., 2001; Haukioja et al., 2002). Leaf age has a strong negative effect on gypsy moth fecundity (Hunter \& Elkinton, 2000).

In contrast to many other phytophagous insects in which preference is decoupled from performance (Gripenberg et al., 2010), the gypsy moth larvae used in the present study successfully recognized host plants that are suitable for their development. The highest preference and performance values were recorded for the leaves of Turkey oak, which had the highest contents of water, nitrogen and soluble proteins as well as total phenols and tannins. Turkey oak was the most preferred and most suitable host and also was the last to produce leaves. On the other hand, leaves of Hungarian oak had the lowest contents of water, total phenols, tannins and soluble proteins and the larvae that fed on these leaves had the lowest preference index and worst performance.

The content of nutrients significantly affects the feeding and oviposition preference of insects. Females of some butterflies prefer to oviposit on plants with a high $\mathrm{N}$ content (Chen et al., 2004; Prudic et al., 2005; Chen et al., 2008). Other butterfly species are more abundant at sites where fertilizers have been applied (Fox et al., 1990). Further, there are reports that the preference of gypsy moth larvae can differ and they choose host plants depending on their nitrogen (Foss \& Rieske, 2003) and alkaloid content (Barbosa \& Krischik, 1987).

Diets with low nitrogen and protein contents negatively affect growth rate, efficiency of assimilation and efficiency of conversion of ingested and digested food into insect biomass (Barbehenn et al., 2004). In addition, low leaf water content is thought to be one of the major factors suppressing nitrogen accumulation and larval growth (Scriber, 1979). To compensate for the lack of nitrogen, insects increase their consumption rate, extend the period of feeding, and/or adjust the activities of digestive enzymes (Lindroth et al., 1997; Clissold et al., 2010; JankovićTomanić, 2012). According to the carbon nutrient balance hypothesis (Tuomi et al., 1988), a high $\mathrm{C} / \mathrm{N}$ ratio indicate greater allocation of plant resources to carbon based defense compounds. However, our study along with some others (Foss \& Rieske, 2003) showed that oaks with a high nutrient content may also contain more tannins. The presence of secondary metabolites may prevent adaptive responses to low nitrogen (Simpson \& Raubenheimer, 2001; Lazarević et al., 2002). Experimentally induced changes in leaf chemistry (lowered $\mathrm{N}$ and starch content and elevated level of secondary metabolites) have a negative effect on gypsy moth performance (Wang et al., 2009).

The shortest development time and highest values of relative growth rate (RGR), relative consumption rate (RCR), assimilation efficiency (AD) and efficiency of conversion of ingested (ECI) and digested food into larval biomass (ECD) were recorded for larvae that were reared on Turkey oak leaves. Foss \& Rieske (2003) indicate that the leaves of Quercus palustris, the most suitable of the five species of oaks they studied on which gypsy moth larvae had the highest growth rate, contain the highest nitrogen content and moderate levels of carbohydrates and tannins. Although gypsy moth growth is negatively correlated with the content of phenolics (Rossiter et al., 1988) this species is considered to be tannin-tolerant. Barbehenn et al. (2009) showed that ingestion of a high level of tannic acid (higher than the total tannin level determined for Turkey oak in our experiment) did not provoke oxidative stress in the midgut and larvae maintained a high growth rate by consuming more of the food containing tannin. In addition, protein utilization efficiency is slightly increased in tannin-treated larvae (Barbehenn et al., 2009). A study of the effects of seasonal changes in the chemical composition of oak leaves on the larvae of gypsy moth indicates they suffer a low level of oxidative stress in both spring and summer and that their better performance in spring is attributed to the higher nutritional quality of leaves at that time (Barbehenn et al., 2013). High protein and water content and low toughness of Turkey oak leaves may also account for the high growth rate of gypsy moth larvae reared on the leaves of this oak in our experiment.

Although sessile oak leaves had a relatively high $\mathrm{N}$ and soluble protein content, the growth and feeding parameters of larvae fed on this oak were significantly worse than those fed on the leaves of Turkey oak. This can be explained by toughness of their leaves, which also accounts for their lower RCR. In locusts leaf toughness reduces nutrient intake and assimilation efficiency, and slows down the passage of food through the gut (Clissold et al., 2009).

Larvae fed on the least suitable host plant, Hungarian oak, prolonged the period they spent feeding but were not able to compensate for low consumption and growth efficiencies. These larvae were unable to achieve the weight of those reared on the other two species of oak. Moreover, in accordance with slow-growth-high-mortality hypothesis (Clancy \& Price, 1987) it is expected that the extended period of feeding will increase the exposure and sensitivity of herbivorous insects to predators, parasitoids and pathogens, resulting in a higher mortality in natural environ- 
ments (Feeny, 1976; Augner, 1995; Häggström \& Larsson, 1995; Benrey \& Denno, 1997; Fordyce \& Shapiro, 2003). Accordingly, the prolonged development of larvae fed on the leaves of Hungarian oak may have a negative effect on the population dynamics of gypsy moths, whereas Turkey oak is at greatest risk of defoliation.

Understanding the relationships between gypsy moth and the different species of oak is important for determining the species composition for forests that will make them less susceptible to defoliation by gypsy moth. It may also help in predicting the northward spread of gypsy moth populations resulting from global warming. The northward expansion of Turkey oak, the most suitable host plant for gypsy moth, can be expected in the future (Hlásny et al., 2011). Consequently, the northern limit to the area in which gypsy moth outbreaks occur is likely to be determined by the northern limit to the distribution of its primary host, Turkey oak (Hlásny \& Turčáni, 2009).

ACKNOWLEDGEMENTS. This research was supported by the project "Studying climate change and its influence on the environment: impacts, adaptation and mitigation" (43007) financed by the Ministry of Education and Science of the Republic of Serbia within the framework of integrated and interdisciplinary research for the period 2011-2014 and the project "Postdocs in the field of biological sciences at Mendel University" (CZ.1.07/2.3.00/30.0017) co-financed by the European Social Fund and the state budget of the Czech Republic.

\section{REFERENCES}

Abbate G., Blasi C., Paura B., Scoppola A. \& Spada F. 1990: Phytoclimatic characterization of Quercus frainetto Ten. Stands in Peninsular Italy. - Vegetatio 90: 35-45.

Augner M. 1995: Low nutritive quality as a plant defense: effect of herbivore-mediated interactions. - Evol. Ecol. 9: 605-616.

AXELROD D.I. 1983: Biogeography of oaks in the arcto-tertiary province. - Ann. Missouri Bot. Gard. 70: 629-657.

Barbehenn R.V., Karowe D.N. \& Chen Z. 2004: Performance of a generalist grasshopper on a $\mathrm{C} 3$ and $\mathrm{C} 4$ grass: compensation for the effects of elevated $\mathrm{CO}_{2}$ on plant nutritional quality. Oecologia 140: 96-103.

Barbehenn R.V., Jaros A., Lee G., Mozola C., Weir Q. \& SalmINEN J.-P. 2009: Hydrolyzable tannins as "quantitative defenses": Limited impact against Lymantria dispar caterpillars on hybrid poplar. - J. Insect Physiol. 55: 297-304.

Barbehenn R.V., Niewiadomski J., Pecci C. \& Salminen J.-P. 2013: Physiological benefits of feeding in the spring by Lymantria dispar caterpillars on red oak and sugar maple leaves: nutrition versus oxidative stress. - Chemoecology 23: 59-70.

BARbosa P. \& KRISCHIK V.A. 1987: Influence of alkaloids on feeding preference of eastern deciduous forest trees by the gypsy moth (Lymantria dispar). - Am. Nat. 130: 53-69.

Benrey B. \& Denno R.F. 1997: The slow-growth-high-mortality hypothesis: a test using the cabbage butterfly. - Ecology $\mathbf{7 8}$ : 987-999.

Berryman A.A. 1996: What causes population cycles of forest Lepidoptera? - TREE 11: 28-32.

BRADFORD M.M. 1976: A rapid and sensitive method for the quantitation of microgram quantities of protein utilizing the principle of protein dye binding. - Analyt. Biochem. 72: 248-254.

CAmbini A. \& Magnoler A. 1997: The influence of two evergreen oaks on development characteristics and fecundity of the gypsy moth. — Redia 80: 33-43.
Chen Y.Z., Lin L., Wang C.W., Yeh C.C. \& Hwang S.Y. 2004: Response of two Pieris (Lepidoptera: Pieridae) species to fertilization of a host plant. - Zool. Stud. 43: 778-786.

Chen Y., Ruberson J.R. \& Olson D.M. 2008: Nitrogen fertilization rate affects larval performance and feeding, and oviposition preference of the beet armyworm, Spodoptera exigua, on cotton. - Entomol. Exp. Appl. 126: 244-255.

Clancy K.M. \& Price P.W. 1987: Rapid herbivore growth enhances enemy attack: sublethal plant defenses remain a paradox. - Ecology 68: 733-737.

Clissold F.J., Sanson G.D., Read J. \& Simpson S.J. 2009: Gross vs. net income: How plant toughness affects performance of an insect herbivore. - Ecology 90: 3393-3405.

Clissold F.J., Tedder B.J., Conigrave A.D. \& Simpson S.J. 2010: The gastrointestinal tract as a nutrient-balancing organ. Proc. R. Soc. (B) 277: 1751-1759.

Couture J.J., Meehan T.D. \& Lindroth R.L. 2012: Atmospheric change alters foliar quality of host trees and performance of two outbreak insect species. - Oecologia 168: 863-876.

Davidson C.B., Gottschalk K.W. \& Johnson J.E. 1999: Tree mortality following defoliation by the European gypsy moth (Lymantria dispar L.) in the United States: a review. - Forest Sci. 45: 74-84.

Ducousso A. \& Bordacs S. 2004: EUFORGEN Technical Guidelines for Genetic Conservation and Use for Pedunculate and Sessile oaks (Quercus robur and Q. petraea). International Plant Genetic Resources Institute, Rome, 6 pp.

ELKInTON J.S. \& LiebHold A.M. 1990: Population dynamics of gypsy moth in North America. - Annu. Rev. Entomol. 35: 571-596.

Fajvan M.A., Rentch J. \& GotTschalk K. 2008: The effects of thinning and gypsy moth defoliation on wood volume growth in oaks. - Trees 22: 257-268.

FARrar R.R., Barbour J.D. \& Kennedy G.G. 1989: Quantifying food consumption and growth in insects. - Ann. Entomol. Soc. Am. 82: 593-598.

FEENY P. 1970: Seasonal changes in oak leaf tannins and nutrients as a course of spring feeding by winter moth caterpillars. Ecology 51: 565-581.

FEENY P. 1976: Plant apparency and chemical defense. In Wallace J.W. \& Mansell R.L. (eds): Recent Advances in Phytochemistry. Plenum Press, New York, pp. 1-40.

Fordyce J.A. \& Shapiro A. 2003: Another perspective on the slow-growth/high-mortality hypothesis: chilling effects on swallowtail larvae. - Ecology 84: 263-268.

Foss L.K. \& RIESKE L.K. 2003: Species-specific differences in oak foliage affect preference and performance of gypsy moth caterpillars. - Entomol. Exp. Appl. 108: 87-93.

Fox L.R., Letourneau D.K., Eisenbach J. \& Nouhuys S.V. 1990: Parasitism rates and sex ratios of a parasitoid wasp: effects of herbivore and plant quality. - Oecologia 83: 414-419.

Giertych M.J., Bakowski M., Karolewski P., Zytkowiak R. \& GRZEBYTA J. 2005: Influence of mineral fertilization on food quality of oak leaves and utilization efficiency of food components by the gypsy moth. - Entomol. Exp. Appl. 117: 59-69.

GotTschalk K.W. 1990: Gypsy moth effects on mast production. In McGee C.E. (ed.): Proceedings of the Workshop: Southern Appalachian Mast Management. University of Tennessee, Knoxville, pp. 42-50.

Gripenberg S., Mayhew P.J., Parnell M. \& Roslin T. 2010: A meta-analysis of preference-performance relationships in phytophagous insects. - Ecol. Lett. 13: 383-393.

GYÖRFI J. 1960: Contributions to the nutritional biology of the gypsy moth (Lymantria dispar L.). - Erdeszeti Kutatasok 56: 279-291 [in Hungarian]. 
HÄGGSTRÖM H. \& LARSSON S. 1995: Slow larval growth on a suboptimal willow results in high predation mortality in the leaf beetle Galerucella lineola. - Oecologia 104: 308-315.

Haukioja E., Ossipov V. \& Lempa K. 2002: Interactive effects of leaf maturation and phenolics on consumption and growth of a geometrid moth. - Entomol. Exp. Appl. 104: 125-136.

Hemming J.D.C. \& LindRoth R.L. 1995: Intraspecific variation in aspen phytochemistry: effects on performance of gypsy moths and forest tent caterpillars. - Oecologia 103: 79-88.

HLÁsNy T. \& TuRČÁNI M. 2009: Insect pests as climate change driven disturbances in forest ecosystems. In Střelcová K., Mátyás C., Kleidon A., Lapin M., Matejka F., Blaženec M., Škvarenina J. \& Holécy J. (eds): Bioclimatology and Natural Hazards. Springer, Berlin, pp. 165-178.

Hlásny T., Holuša J., ŠTĚPÁneK P., Turčán M., Sitková Z. \& ZAJíčKOVÁ L. 2011: Expected impacts of climate change on forests: Czech Republic as a case study. - J. Forest Sci. 57: 422-431.

Horvat I., Glavač V. \& Ellenberg H. 1974: Vegetation of Sudosteuropas. Geobotanica selecta, Band IV. Gustav Fischer Verlag, Stuttgart, 768 pp.

Hunter A.F. \& ElKinton J.S. 2000: Effects of synchrony with host plant on populations of a spring-feeding Lepidopteran. Ecology 81: 1248-1261.

Ivashov A.V., Boyko G.E. \& Simchuk A.P. 2002: The role of host plant phenology in the development of the oak leafroller moth, Tortrix viridana L. (Lepidoptera: Tortricidae). - Forest Ecol. Manag. 157: 7-14.

Jalas J. \& Suominen J. 1987: Atlas Florae Europaeae. Distribution of Vascular Plants in Europe. Vol. 2. Cambridge University Press, Cambridge, 206 pp.

JANKOVIĆ-Tomanić M. 2012: Effects of Temperature and Food Quality on Variability of Fitness Components and Physiology of Digestion in the Gypsy Moth Larvae Lymantria dispar L. $\mathrm{PhD}$ Thesis, University of Belgrade, $230 \mathrm{pp}$.

Kleiner K.W. \& Montgomery M.E. 1994: Forest stand susceptibility to the gypsy moth (Lepidoptera: Lymantriidae): Species and site effects on foliage quality to larvae. - Environ. Entomol. 23: 699-711.

Konstantinidis P., Chatziphilippidis G., Tsiourlis G. \& TsiontSIS A. 2002: Taxonomy and ecology of plant communities of Quercus frainetto Ten. (Q. conferta Kit.) forests in Greece. Israel J. Plant Sci. 50: 145-154.

KuRIR A. 1953: The food plants of the gypsy moth: A contribution to knowledge of its feeding habits. - J. Appl. Entomol. 34: 543-586.

Lazarević J., Perić-Mataruga V., Stojković B. \& Tucić N. 2002: Adaptation of the gypsy moth to an unsuitable host plant. Entomol. Exp. Appl. 102: 75-86.

Liebhold A.M., Gottschalk K.W., Muzika R.M., Montgomery M.E., Yong R., O’Day K. \& BrooKs K. 1995: Suitability of North American Tree Species to the Gypsy Moth: A Summary of Field and Laboratory Tests. USDA Forest Service Gen. Tech. Rep. NE-211. Radnor, PA, 34 pp.

Lindroth R.L., Klein K.A., Hemming J.D.C. \& Feuker A.M. 1997: Variation in temperature and dietary nitrogen affect performance of the gypsy moth (Lymantria dispar L.). - Physiol. Entomol. 22: 55-64.

Magnoler A. \& CAMBINI A. 1997: Consumption and utilization of leaf tissue of Quercus suber L. and Quercus ilex L. by Lymantria dispar L. larvae. — Redia 80: 99-106.

MaKKar H.P.S. 2000: Quantification of Tannins in Tree Foliage. A Laboratory Manual for the FAO/IAEA Co-ordinated Research Project on Use of Nuclear and Related Techniques to Develop Simple Tannin Assays for Predicting and Improving the Safety and Efficiency of Feeding Ruminants on Tanniniferous Tree Foliage. Joint FAO/IAEA of Nuclear Techniques in Food and Agriculture. Animal Production and Health Sub-programme, FAO/IAEA Working Document. IAEA, Vienna, 26 pp.

MaKkar H.P.S., Dawra R.K. \& Singh B. 1988: Determination of both tannin and protein in a tannin-protein complex. $-J$. Agric. Food Chem. 36: 523-525.

MakKar H.P.S., Bluemmel M., Borowy N.K. \& BeCKer K. 1993: Gravimetric determination of tannins and their correlations with chemical and protein precipitation methods. - J. Sci. Food Agric. 61: 161-165.

Marović R., Maravić M., Jančić G. \& Lazarev V. 1998: Gypsy moth outbreaks in Serbia. In Adamović Ž. (ed.): Gypsy Moth Outbreaks in Serbia. The Entomological Society of Serbia, Belgrade, pp. 1-12.

MARTIN M.M. \& VAN'T Hof H.M. 1988: The cause of reduced growth of Manduca sexta larvae on a low-water diet: increased metabolic processing or nutrient limitation? - J. Insect Physiol. 6: 515-525.

MatTSON W.J. 1980: Herbivory in relation to plant nitrogen content. - Annu. Rev. Ecol. Syst. 11: 119-161.

Mrdaković M., Perić Mataruga V., Ilijin L., Janković Tomanić M., MirČić D. \& LAZAREVIĆ J. 2013: Response of Lymantria dispar (Lepidoptera: Lymantriidae) larvae from differently adapted populations to allelochemical stress: Effects of tannic acid. - Eur. J. Entomol. 110: 55-63.

MuziKa R.M. \& LiebHold A.M. 1999: Changes in radial increment of host and nonhost tree species with gypsy moth defoliation. - Can. J. Forest Res. 29: 1365-1373.

MuziKa R.M. \& LiebHold A.M. 2001: A critique of silvicultural approaches to managing defoliating insects in North America. - Agr. Forest Entomol. 2: 97-105.

Naidoo R. \& Lechowicz M.J 2001: The effects of gypsy moth on the radial growth of deciduous trees. - Forest Sci. 47: 338-348.

Ossipov V., Haukioja E., Ossipova S., Hanhimäki S. \& Pihlaja K. 2001: Phenolic and phenolic-related factors as determinants of suitability of mountain birch leaves to an herbivorous insect. - Biochem. Syst. Ecol. 29: 223-240.

PeARSE I.S. 2011: The role of leaf defensive traits in oaks on the preference and performance of a polyphagous herbivore, $\mathrm{Or}$ gyia vetusta. - Ecol. Entomol. 36: 635-642.

Pernek M., Pilaš I., Vrbek B., Benko M., Hrašovec B. \& Milković J. 2008: Forecasting the impact of the gypsy moth on lowland hardwood forests by analyzing the cyclical pattern of population and climate data series. - Forest Ecol. Manag. 255: $1740-1748$

Ponomarieva V.V. \& Plotnikova T.A. 1975: Determination of the Content and Composition of Organic Matter in Peat Soils. Methods of the Determination of Humus Content and Composition in the Soils (Mineral and Peat). Dokuchaev Central Soil Science Museum, St. Petersburg [in Russian].

Prudic K.L., Oliver J.C. \& Bowers M.D. 2005: Soil nutrient effects on oviposition preference, larval performance and chemical defense of a specialist insect herbivore. - Oecologia 143: 578-587.

RHEE K.C. 2001: Unit B1.2. Determination of total nitrogen. In Wrolstad R.E., Acree T.E., Decker E.A., Penne M.H., Reid D.S., Schwartz S.J., Shoemaker C.F., Smith D. \& Sporns P. (eds): Handbook of Food Analytical Chemistry, Pigments, Colorants, Flavors, Texture and Bioactive Food Components. John Wiley \& Sons, New York, pp. 95-113.

Rossiter M.C. 1994: Maternal effects hypothesis of herbivore outbreak. — Bioscience 44: 752-763. 
Rossiter M.C., Schultz J.C. \& BALdwin I.T. 1988: Relationships among defoliation, red oak phenolics, and gypsy moth growth and reproduction. - Ecology 69: 267-277.

Salminen J.P., Ossipov V., Haukioja E. \& Pihlaja K. 2001: Seasonal variation in the content of hydrolysable tannins in leaves of Betula pubescens. - Phytochemistry 57: 15-22.

Schopf A., Hoch G., Klaus A., Novotny J., Zubrik M. \& SCHAFELLNER C. 1999: Influence of food quality of two oak species on the development and growth of gypsy moth larvae. In Lieutier F., Mattson W.J. \& Wagner M.R. (eds): Physiology and Genetics of Tree-Phytophage Interactions. INRA, Paris, pp. 231-247.

SCRIBER J.M. 1979: Effects of leaf-water supplementation upon post-ingestive nutritional indices of forb-, shrub-, vine-, and tree feeding Lepidoptera. - Entomol. Exp. Appl. 25: 240-252.

Şen A., Quilho T. \& Pereira H. 2011: Bark anatomy of Quercus cerris L. var. cerris from Turkey. - Turkish J. Bot. 35: 45-55.

SimPSON S.J. \& RAUBENHEIMER D. 2001: The geometric analysis of nutrient-allelochemical interactions: A case study using locusts. - Ecology 82: 422-439.

Traw M.B., Lindroth R.L. \& Bazzaz F.A. 1996: Decline in gypsy moth (Lymantria dispar) performance in an elevated $\mathrm{CO}_{2}$ atmosphere depends upon host plant species. - Oecologia 108: $113-120$.
Tuomi J., Niemela P., Chapin F.S. III, Brayant J.P. \& Siren S. 1988: Defensive response of trees in relation with their carbon/ nutrient balance. In Mattson W.J., Levieux J. \& Dagan B.C. (eds): Mechanisms of Woody Plant Defenses Against Insects. Springer, New York, pp. 57-73.

VALENTINE H.T. \& TALERICO R.L. 1980: Gypsy moth larval growth and consumption on red oak. - Forest Sci. 26: 599-605.

Valentin H.T., Wallner W.E. \& Wargo P.M. 1983: Nutritional changes in host foliage during and after defoliation, and their relation to the weight of gypsy moth pupae. - Oecologia 57: 298-302.

VAN AsCh M. \& VisSER M.E. 2007: Phenology of forest caterpillars and their host trees: The importance of synchrony. Annu. Rev. Entomol. 52: 37-55.

WALDBAUER G.P. 1968: The consumption and utilization of food by insects. - Adv. Insect Physiol. 5: 229-288.

WANG X.W., Ji L.Z., Zhang Q.H., LiU Y. \& WANG G.Q. 2009: Effects of elevated $\mathrm{CO}_{2}$ on feeding preference and performance of the gypsy moth (Lymantria dispar) larvae. - J. Appl. Entomol. 133: 47-57.

Received March 25, 2013; revised and accepted January 29, 2014 Prepublished online April 23, 2014 